\title{
DYNAMIC CONTROL OF A ROBOT ARM USING CMAC NEURAL NETWORKS
}

\author{
G. Cembrano, G. Wells, J. Sardá and A. Ruggeri
}

Instituto de Robótica e Informática Industrial, Univ. Politécnica de Cataluña-Consejo Superior de Investigaciones Científicas, Gran Capitán 2-4, Planta 2, Barcelona 08034, Spain (gcembrano@iri.upc.es)

\begin{abstract}
Ncural identification and control techniques arc well-suitcd to the problem of controlling robot dynamics. This paper describes the use of CMAC networks for the adaptive dynamic control of an orangc-harvesting robot. Among the various ncural-nctwork paradigms available, the CMAC model was chosen in this casc becausc of its fast convergence and on-linc adaptation capability. The solution of this dynamic control problem with CMAC is an cncouraging demonstration of "cxpcricncc-based", as opposed to model-bascd, control tcchniques and is a good cxamplc of the use of on-line learning in adaptive ncural control
\end{abstract}

Kcywords: Ncural networks, identification, adaptive control, robotics, CMAC

\section{INTRODUCTION}

The problem of dynamic control of a robot arm consists of gencrating the appropriatc motor commands at the joints so that the end-cffector follows a desired trajectory as preciscly as possible, cven under extreme specd and payload conditions. The efficient solution of the dynamic control problem using conventional control schemes would requirc a thorough knowledge of the system bchaviour, translatcd into a very accuratc nonlincar mathcmatical model, which is typically very hard to obtain (Zomaya and Nabhan, 1993). The cffects of friction and incrtia, for example, depend on the system statc, and the addition of payloads to the systcm may greatly affect the ovcrall dynamic bchaviour.

In this context, ncural identification and control techniques are very well-suitcd to the problem of controlling robot dynamics. Firstly, the ability to learn nonlincar bchaviours through the presentation of appropriatc cxamples of inputs and outputs helps to overcome the modclling difficultics.
Sccondly, the on-linc learning capabilitics of ncural networks make them very efficient in adaptive control schemes.

A gencral approach to ncural adaptive control, proposed in (Narcndra and Parthasarathy, 1990), consists of an indirect model-rcference adaptive schemc with a scrics-parallcl structurc. Similarly, scveral concepts rclated to ncural adaptive control arc treatcd in (Hunt et al., 1993) and (Ccmbrano and Wells, 1992). A number of more refined versions of backpropagation have becn proposcd in the litcrature for adaptive control and proved in a varicty of applications c.g. (Tzirkcl-Hancock and Fallsidc, 1992; Hoskins et al., 1992; SbarbaroHofer et al., 1993; Lokc and Ccmbrano, 1994). In addition, the CMAC neural network (Ccrebellar Model Articulation Controller), originally devcloped by (Albus, 1975), has also becn used in neural adaptive control schemes. It has the advantage of much faster convergence than backpropagation networks, and excellent model-tracking capabilitics (Ananthraman and Garg, 1993). Other re scarchers (Miller et al., 1987; Miller, 1994) studied 
a CMAC-based lcarning control system for the dynamic control of robot manipulators with multiple fecdback scnsors and multiple command variables. In this scheme, a CMAC network is used to adaptivcly lcarn an approximatc dynamic model of the controlled robot in appropriate regions of the system statc space. The CMAC learns the unknown nonlincar mapping between the sensor outputs and the system command variables from on-line obscrvations of cach during systcm opcration.

This paper describes the use of CMAC networks for the adaptive dynamic control of an orange harvesting robot. The problem derives from the ESPRIT III project "Robot Control based on Neural Network Systems", which aimed to demonstratc the advantages of neural networks in sevcral areas of robot control. One of the industrial applications in this project was a custom-mado prototype devcloped by the Italian rescarch institutc Consorzio per la Riccrca dell'Agricoltura del Mczzoggiorno (CRAM) for orange harvesting, which must perform very fast movements under strict requirements of positioning accuracy. The use of CMAC for this problem is described in the paper.

The modelling and controller design of the robot arm werc carricd out in two phases. In the first stagc, the prototype robot was not yct opcrative and no ficld data werc availablc for generating a model of the dynamics, so the development of the controller had to rely on a thcorctical model supplied by the manufacturer. In the sccond stage, when mcasurements could be taken with the actual robot, a thorough set of expcrimental arm clongation data was provided by the manufacturer, and a new model of the dynamics was developed by the authors. A ncural-network model was preferred, since it provided better approximation capabilitics than the theoretical model.

The first stage of the controller design provided some important rcsults. It was uscful for demonstrating the ability of CMAC to control a very complex dynamic bchaviour similar to the robot dynamics. Despitc the differences between the theorctical model and the real bchaviour of the robot the results of this stage showed that CMAC can cfficicntly approximatc the implicit relationship between the end-effector trajectory and the motor commands, adapting the ncural representation on-linc. This result had the rcasonable implication that CMAC will latcr be able to lcarn the real robot dynamics, since the ncural structure is at all timcs independent of the robot model that gencrated the training data; it mercly cmulatcs an input-output rclationship. Furthcrmorc, at this stage, the charactcristics of the CMAC lcarning and on-linc adaptation processes were studicd in depth, scveral control structures werc designed and tested, and a preliminary tuning of the CMAC parameters for the problem was performed.

In the sccond stage, a ncural identificr of the robot was used in place of the system model, within the same control scheme as in the first stage. A PID controller was used to provide nominal systcm control, and thus gencratc initial training data for the CMAC network. It was shown that the CMAC control scheme can achicve significantly improved control performance over the lincar controller alone, by virtuc of using CMAC network learning, to rclate the obscrvations of the tracking crror to the controls bcing applicd.

The development of the CMAC controller using data generated by the theorctical model are described in Sections 4 and 5 . Section 6 deals with the application of the CMAC controller in a simulated scheme incorporating the expcrimentally obtained neural model of the robot arm. The conclusions of the work, and futurc cxtensions, are prescnted in Scction 7.

\section{THE CMAC NEURAL NETWORK}

The CMAC network, based on the cercbellar modcl of ncuromuscular control, is basically a nonlincar tablc-look-up tcchnique which maps cach $\mathrm{N}$-dimensional input state-space vector to a corresponding output vector of the samc or a different dimcnsion. Each input vector activates $\mathrm{cx}$ actly $C$ ovcrlapping input receptive ficlds, where $C$ is a variable parametcr represcnting the extent of gencralization desired within the state space The potentially very large virtual state space is mapped to a smaller physical weight table using a fixcd random hashing tablc. Output values are computed simply as the sum of the $C$ weights addressed by a given set of inputs. A supervised training method, rescmbling the WidrowHoff rulc, is used to adjust the CMAC memory valucs, based on obscrvations of the output crror

In the CMAC network, it is the input weightaddressing scheme which is nonlincar, whercas the output is a linear sum of weights. This charactcristic provides a smooth crror surface, thus improving convergence to a global minimum. Figurc 1 shows a single point lcarned for an arbitrary bidimensional function, with a gencralization factor of $C=8$. The pyramidal shapc indicates that the surrounding inputs producc output valucs which decrcasc lincarly with distance. All sampled (learned) points of a function define an output surface formed by overlapping pyramids (a hypcrsurface for more than 2 inputs). For higher gencralization factors, the pyramid spreads over a wider arca, and it becomes narrower for smaller 


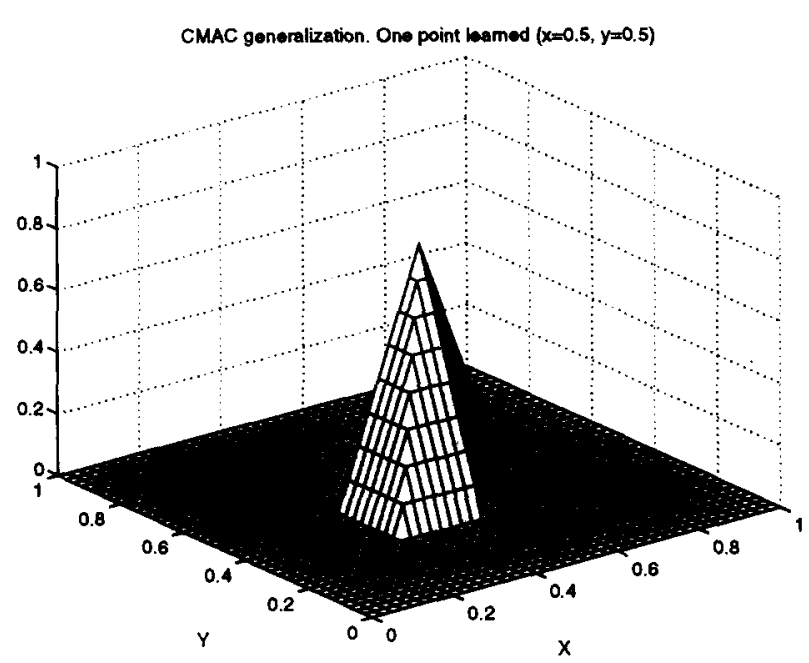

Fig. 1. Output surface after learning a single point $(x=0.5$ and $y=0.5$ ) of an arbitrary two-dimensional function. The scale was chosen so as to aid visualization of the generalization effect. $C=8$

valucs. For $C=0$, the CMAC memory acts as a lincar look-up table. Converscly, a very large gencralization factor would producc a bchaviour rescmbling that of a fccdforward backpropagation network.

In the CMAC nctwork, the lcarning process and the ncuron activations are local, whercas in a fecdforward network (FFN), all the ncurons arc involved in the computation of an output. This fact makcs CMAC much faster than FFNs, and capable of adaptation in spccific regions of the input-output spacc, without requiring completc retraining. However, CMAC may, in some cases, fail to achicve the good gencralization propertics of FFNs, especially when very small $C$ factors are used. In general, the $C$ factor must be chosen as a compromise between the fast, local activation of a very few ncurons with little capabilitiy of gencralization, and the slower activation of a larger number of neurons with a good gencralization bchaviour.

\section{PROBLEM DESCRIPTION}

The orangc-harvesting robot consists of a large 3-dof hydraulic arm which holds two smaller 3dof tclescopic harvesting arms with a cutting cndcffector for the harvesting opcration. A camcra is mounted on cach harvesting arm. The larger arm is heavy and slow and was conccived mainly for approximating the position of the harvesting arms to the correct height on the trec. The harvesting arms arc light-wcight structurcs which must perform very fast movements under strict precision requirements, cven with high accelerations. The control problem dealt with in this work concerns the tclescopic movement of the light-wcight harvesting arm (a diagram of the arm is shown in Fig. 2).

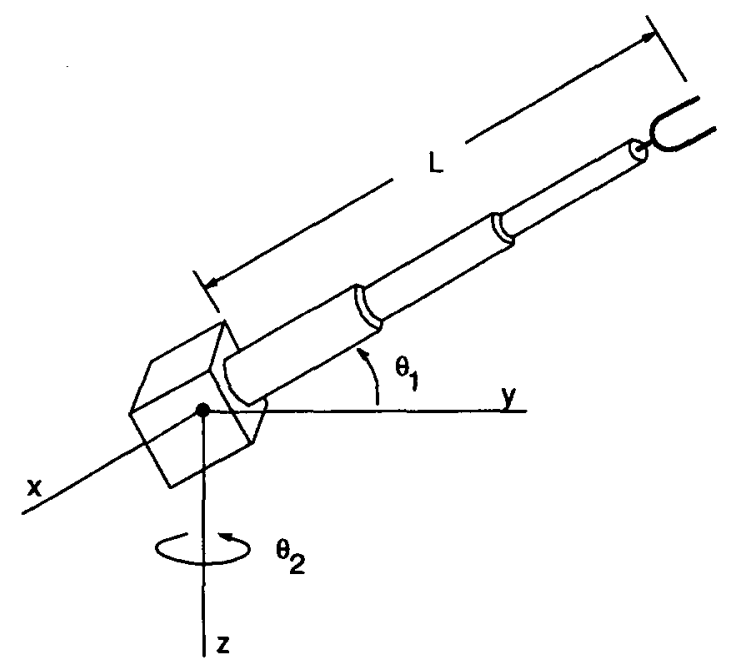

Fig. 2. Schematic diagram of the 3-dof telescopic harvesting arm.

\subsection{Theoretical model of the robot arm}

This model was a variable-structure, piccewisclincar approximation with four sccond-order lincar transfer functions which represent the $d y-$ namic behaviour of the arm under different conditions of clongation and specd. This scheme is derived from the fact that no single lincar model could accuratcly represent the whole range of $d y-$ namic systcm responses, so the systcm output was obtaincd from the most appropriatc model in the current region of the statc spacc.

The variable-structure model introduces a complex nonlincar switching bchaviour, which is a very difficult problem for classical control techniques. The model takes account of variations in the incrtia moments and friction cocfficicnts depending on the clongation and spced of the arm. The prototype incorporates a programmable PID controller which provides the torque signals to the harvesting-arm actuators in a closed-loop control system. A scheme of the robot model is shown in Fig. 3.

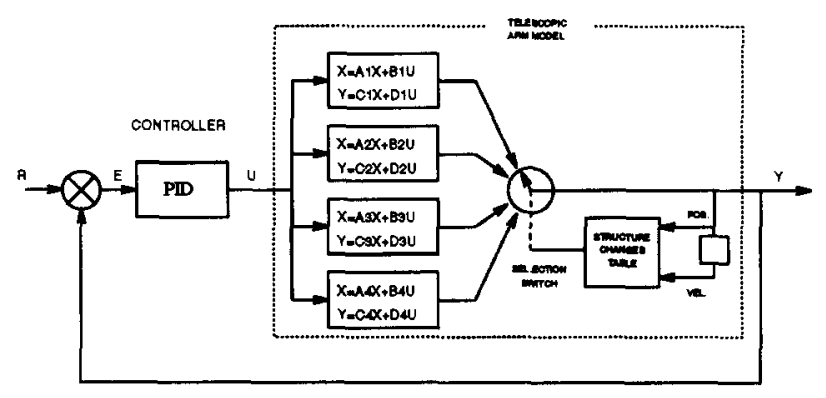

Fig. 3. Variable-structure telescopic robot model.

\section{CONTROLLER DESIGN}

\subsection{Linear control and reference signal}

Since the system would otherwisc produce unstablc responses, a PID controller is connected in 
parallcl with the CMAC controller, thus providing nominal system control in order to generate the initial training data for the CMAC. The controller was designed as a classical PID, tuncd in order to cnsurc the best possible response for all of the four lincar models, and it produces a good closedloop tracking response for a complex reference trajectory.

The shape of the reference trajectory was designed in order to test the controller performance under the worst conditions. The robot's responsc is good, but shows somc lag for stcp inputs, and instability in regions where the system structure changes rapidly. The graphs in Fig. 4 show the refcrence trajectory, the dynamics of the structural changes, and their influence on the control and output signals. This highly nonlincar bchaviour must be learned by the CMAC adaptive controller. Figurc 5 shows a detail of the switching bchaviour.

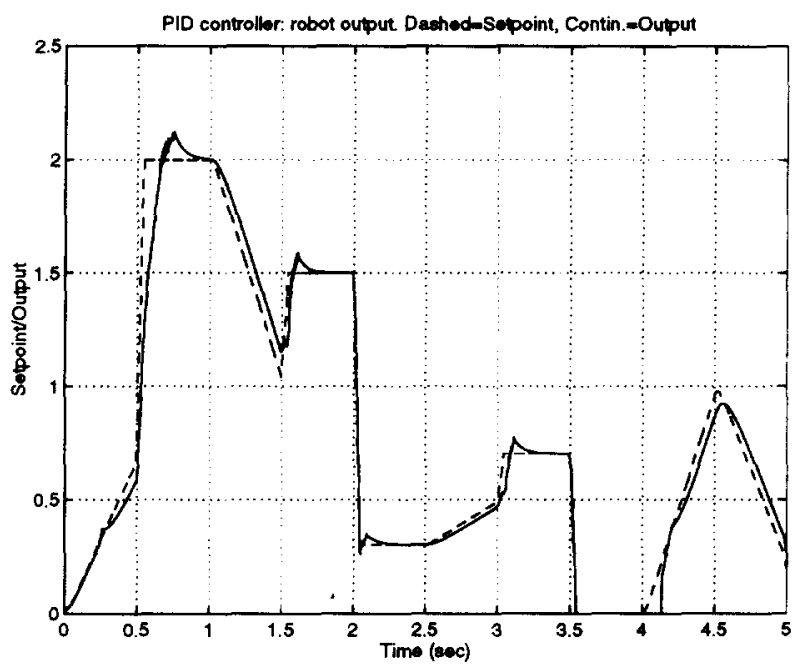

Fig. 4. PID tracking

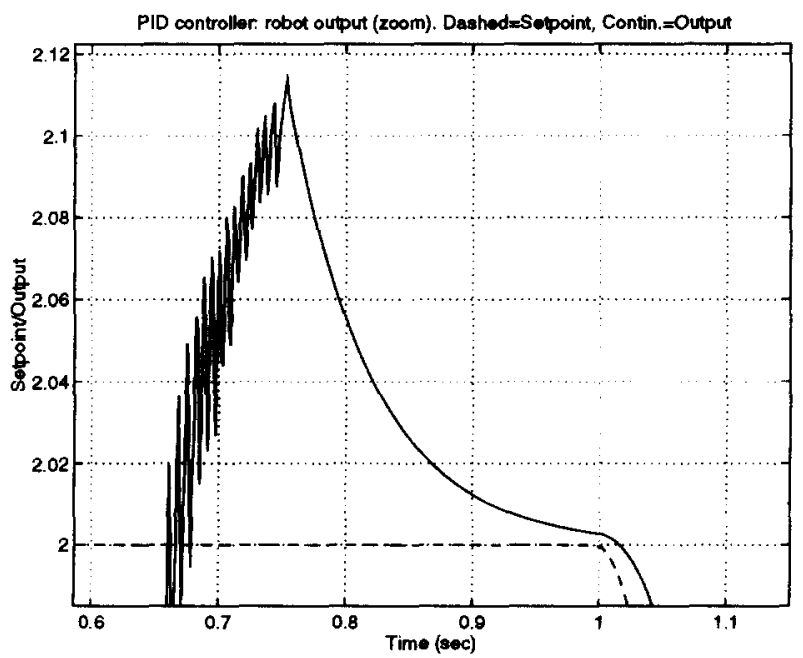

Fig. 5. PID tracking (detail showing complex switching behaviour). The ripple is not due to added noise, but is the effect of dynamic structural changes, which must be learned for good tracking performance.

\subsection{CMAC control scheme}

The CMAC network is used in a closed-loop control systcm to adaptivcly learn the inverse dynamics of the robot, thus predicting the actuator torques required to makc the robot follow a desircd trajectory. These torques are a function of the current crrors in the joint position and velocity, and arc uscd as fecdforward tcrms in parallel with a fixcd-gain PID lincar fecdback controller. The control signal input to the robot is the sum of the terms from the CMAC module and the fecdback controller. The control scheme, based on that uscd by Miller (Miller et al., 1987), is shown in Fig. 6.

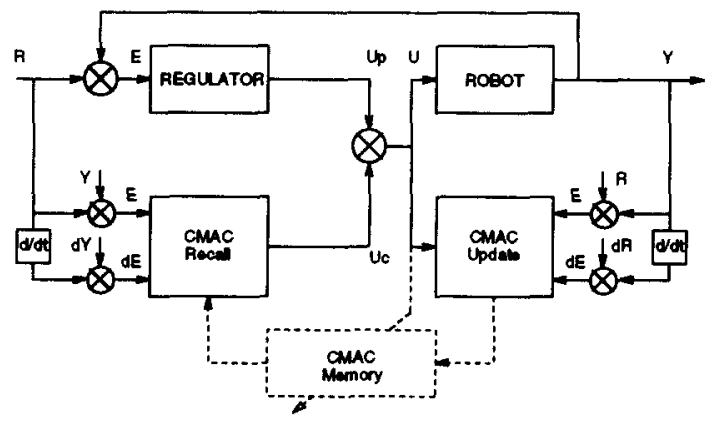

Fig. 6. CMAC control scheme.

Training is performed on-linc in real time, which is possible duc to the localized nature of the CMAC receptive ficlds and the specd of the CMAC algorithm. At the beginning, the CMAC memory is initialized to zero values. The PID controller thercfore provides all of the initial robot control signals, producing the robot movements which gencratc the initial training data for the CMAC. After cach control cycle, the CMAC weights are updated, based on the current crrors in position and velocity. The crror betwecn the actual control signal input to the robot (the sum of the PID and CMAC signals), and the control signal the CMAC produces when given the current errors as inputs, is used in the Widrow-Hoff rulc to adapt the weights. Thus, the CMAC is trained on the inverse dynamic response of the robot. As training progresses, the CMAC output signal improves, and the resulting control crror dccrcases, diminishing the control cffort required by the PID controller and increasing that of the CMAC. The CMAC therefore progressively takes over control from the PID. As will be shown later, the CMAC controller cventually provides a better control signal than the PID, by learning dircctly from the measurements of applied controls and the trajectory-tracking performance. 


\section{CMAC LEARNING OF THE INVERSE DYNAMICS}

\subsection{Internal mapping}

The internal mapping learned by the CMAC memory is very much dependent on the shape of the reference signal and the gencralization factor. A representation of the CMAC output mapping for the first point lcarncd at the beginning of the first training cyclc has the shapc of a conc, whosc basc has a width that depends on the magnitude of the gencralization factor (QF), as was shown in Fig. 1. The subscquent points form a chain of overlapping concs which represents the inverse dynamics of the robot model as a scrics of ridges and valleys. Figure 7 illustrates how this represents the control signal for one completc training cycle, which is related to the evolution of the reference signal.

It must be pointed out that the initial topography rescmbles the shapes of the various portions of the reference signal (the initial crror follows the setpoint because there is still no robot response for the first time stcp, and the PID is designed as dominantly proportional). In addition, the crror surface is divided into a scrics of parallel ridges. Since structural changes depend on the position and velocity, it can be deduced that the scparation between the different ridges in the topography is duc to structural changes. The widths of the peaks and valleys depend on the gencralization factor. For higher gencralization values, the chain of concs forms a smoother topography, whosc ridges and valleys fusc. Lower gencralization produces sharper topographics, with more scparation between the ridges. This characteristic is relcvant to the variable structure problem. As may be obscrved in Fig. 7, the structurc-changing bchaviour is reflected in the number of ridges and valleys in the topography. With higher gencralization factors, the gencralization effect smoothes out the ridges and valleys, and with lower factors they become sharper and more separate, increasing the resolution of the control signal. In other words, part of the dynamics of the structural changes is lost with overgencralization.

The cffect on the memory topography of increasing the gencralization factor is observed in Fig. 8. The robot output begins to diverge from the refcrence trajectory as the gencralization factor is increased. The learning time also increases, duc to the larger number of memory values which must be updated at each cyclc. This is an undesirable effect for the real-time application. The value of the gencralization parameter must therefore bc chosen carcfully.
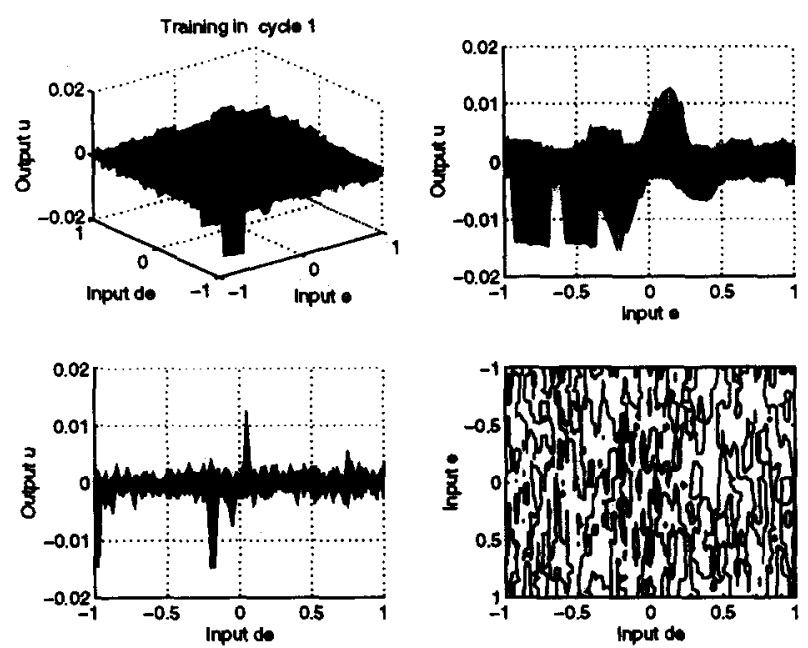

Fig. 7. CMAC memory mapping after one training cycle, with generalization factor $C=8$. Labels $e$ and de represent the error and error derivative. Label $u$ is the control signal. The diagram shows a perspective view and projections on all 3 planes.
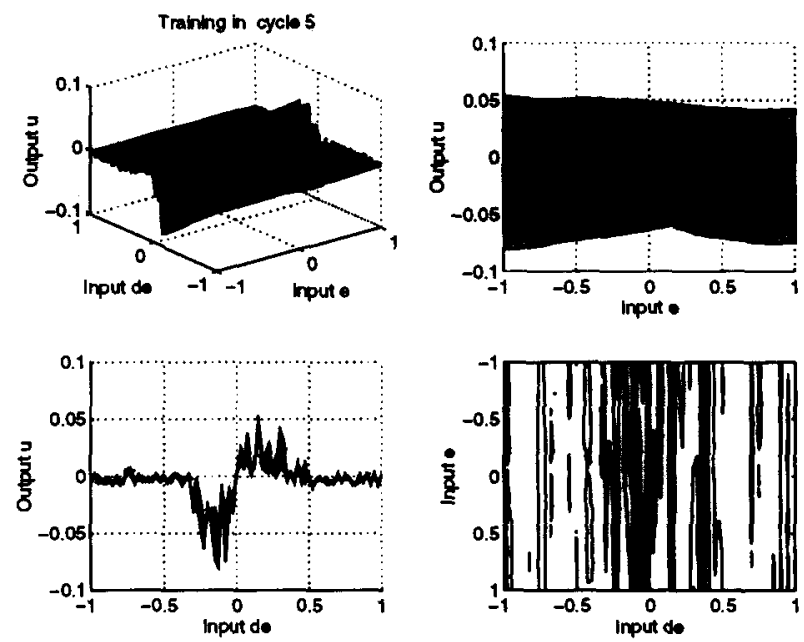

Fig. 8. CMAC memory mapping after the fifth training cycle with generalization factor $C=128$. Labels $e$ and de represent the error and error derivative. Label $\mathbf{u}$ is the control signal. The diagram shows a perspective view and projections on all 3 planes.

\subsection{On-line adaptation}

During the initial training cycles, the CMAC controller learns little more than the behaviour of the PID. In the CMAC memory topography, no further cnlargement is observed in the peaks and vallcys. Any deviation of the command that is not represented in the CMAC momory is balanced by the PID controller. Likewisc, the inverse dynamic bchaviour of the robot, that the PID could not adcquatcly respond to, is lcarned and represented in the CMAC memory, thus supplementing the control signal.

As the number of on-linc training cycles increases, the CMAC controller output contributes more and more to the overall control signal input to the robot, and the crror surfacc changes accordingly. The process continucs until a point of cquilibrium 
is reached, where both controllers contribute to the control signal. After this point, the CMAC controller's influcnce on the robot response is at least as strong as that of the PID, and it begins to lcarn the responses that rcsult from applying its own control signal. The CMAC's bchaviour becomes adaptive, directed by the fecdback error signal, and improvement in the robot's response begins to be obscrved.

Figure 9 shows the results of CMAC control aftcr 14 learning cycles. Despitc abrupt changes in position imposed by the reference trajectory, the CMAC control scheme is able to track it very closcly, cven for the fastcr, almost instantancous movements. The only significant deviations from the setpoint occur at the tops of the stcp portions of the trajectory, where many structural changes occur during a very short interval. Although this response was observed for both CMAC control and PID control, this problem is highly unlikcly to arise with the real robot, since any structural variations it may display will occur in a morc continuous manner. Even after the CMAC training has stabilized for this trajectory, some differences in performance may be obscrved from onc cycle to the next. Neverthcless, tracking remains stable and accuratc. The results of this test show that the CMAC can efficiently learn the inverse dynamics of this complex robot model and improve the results of applying classical PID control alonc.

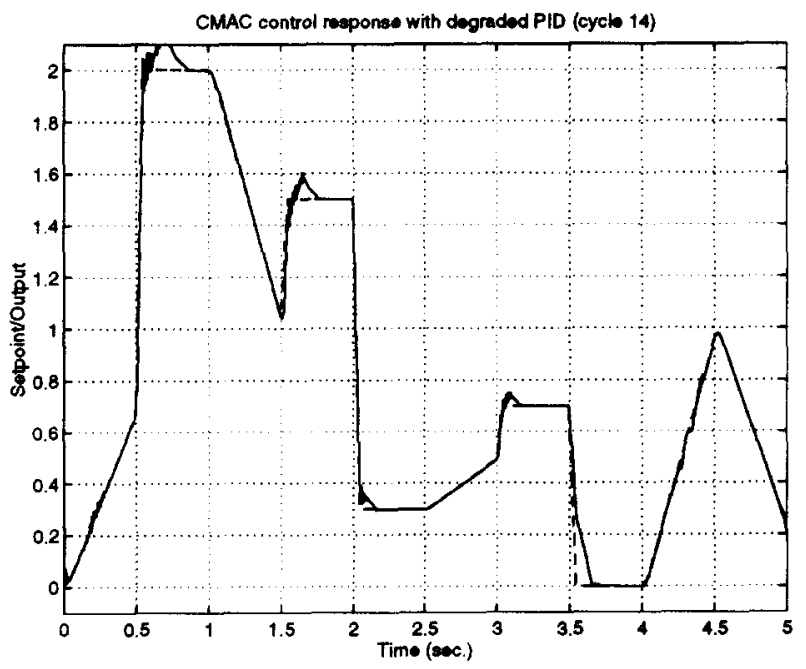

Fig. 9. CMAC Control vs. setpoint.

Duc to the fact that the PID controller was optimally designed for the theorctical robot model, the PID control results arc very good and the tracking improvement with the CMAC controller only slightly appreciable. Howcver, it would be impossiblc to obtain such results in real conditions with the PID controller alone, where important deviations from the model would appear. In this case, the theoretically designed PID would not perform satisfactorily, and no explicit representation of the robot would be available, with which to rcdesign it. It is in those conditions that the ability of CMAC to learn from the experimental data of tracking crror and applicd control is cspccially uscful, sincc it will learn to producc a bettcr control signal than that of the model-dependent PID controllcr.

\section{RESULTS OF CMAC CONTROL ON THE EXPERIMENTAL ARM MODEL}

With a comprehensive set of measurements of the control, position and velocity signals in clongation and retraction movements provided by the manufacturcr, a better simulator of the robot dynamics was developed. Duc to the highly nonlincar naturc of this systcm, a ncural nctwork model was preferred to the piccewisc linear approximation used beforchand. The identification process was carricd out according to the methods described in (Cembrano and Wells, 1992) and the best results wcre obtained with a 3-laycr fecdforward ncural network with 5 inputs, 1 output and 8 hidden nodes. The inputs arc the current state of the systcm (position and vclocity) and the current control action, as wcll as delaycd obscrvations of these signals. The output is the next position of the system. Figure 10 shows an example of the identification results with this ncural nctwork for an arbitrary clongation movement of the arm. The plot represents the clongation of the endeffector vs. time, with the identifier and with the real systcm. A more detailed description of the identification process and its results on several robot movements may be found in (Cembrano and Wells, 1995)

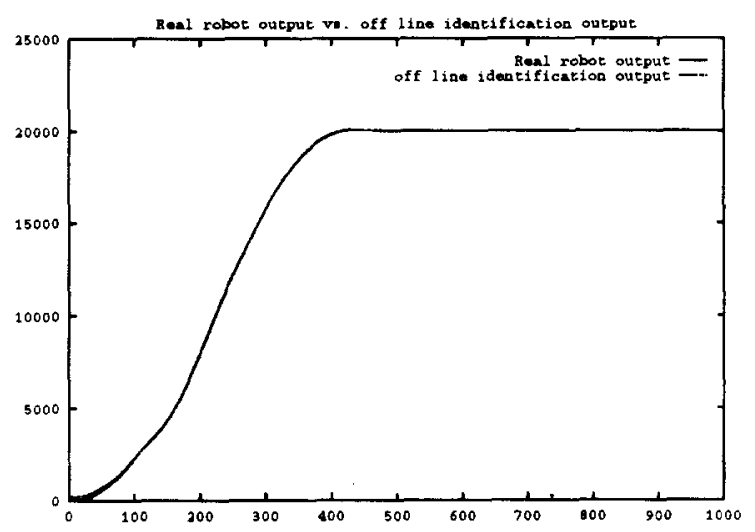

Fig. 10. Identification results for an elongation movement using the newral identifier.

The ncural identificr was incorporatcd in the CMAC control scheme in place of the lincar modcl. In these conditions, the PID controller was not optimal for the process, and any improvements on the PID paramcters had to be performed on a trial-and-crror basis. Figure 11 shows the control performance with the PID alone 
for an clongation movement. The plot represents clongation vs. time for the observed and reference trajectorics.

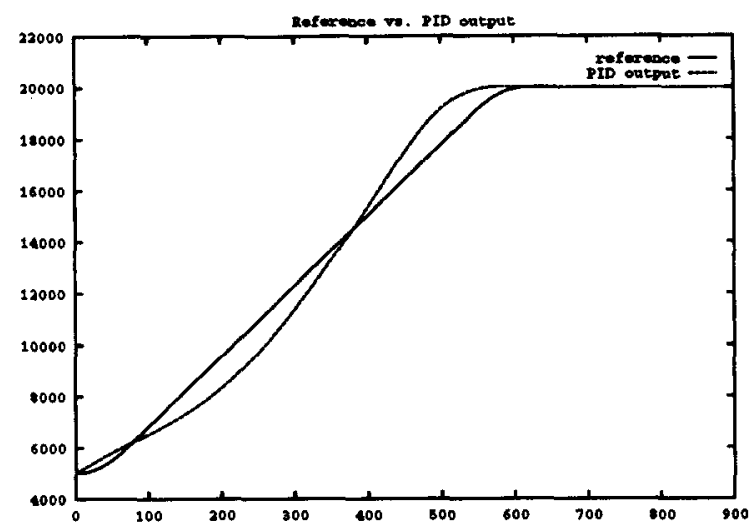

Fig. 11. PID control in an elongation movement. Elongation ve. time for reference and observed trajectories.

The CMAC controller was trained with the new robot model, as described in Section 6. After the 5th lcarning cyclc, the CMAC controller had learned on-line to control the systcm, so that the combined control produced a significantly better tracking performance than the PID alonc, as shown in Fig. 12.

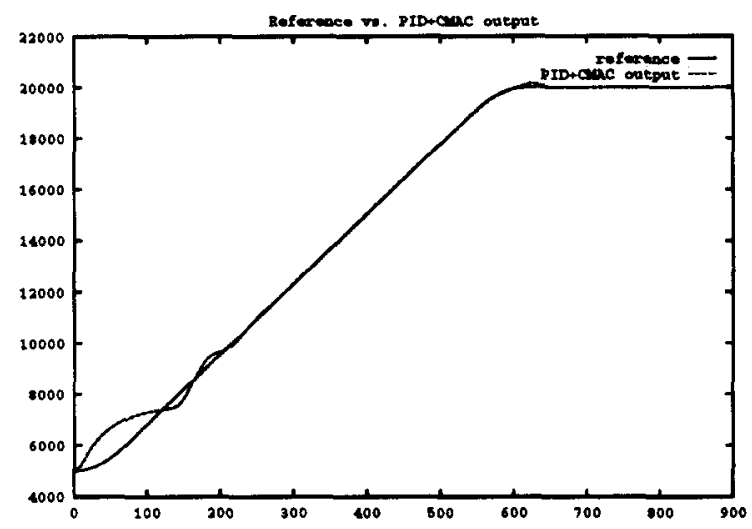

Fig. 12. CMAC Control for the same elongation movement as in Fig. 11.

These results illustratc the capabilitics of the proposcd CMAC control scheme to lcarn to control a very complex systcm, based on on-line obscrvations of system performance. Even though a lincar controller is initially requircd to provide the nominal control trajectorics from which the CMAC can bcgin lcarning, the above results show that the trained CMAC controller can crentually outperform the PID controller. As long as the initial controller provides a stable output, its performance is not critical. This fact is important, since it implics that the initial controller design process is madc simpler, and subscquent improvements can be achicred through lcarning.

\section{CONCLUSIONS AND FUTURE WORK}

The work describcd in this paper was carricd out as part of a rescarch project aimed at demonstrating the use of ncural networks in several aspects of robot control. The control of robot dynamics under strict requirements of trajectory tracking of partially unknown or timc-varying nonlincar systcms has traditionally becn a difficult problem in robotics. Thereforc, this was considered a challeging problem for the usc of ncural networks.

Among the various ncural-nctwork paradigms available, the CMAC model was chosen for this dynamic control application becausc of its fast convergence and on-line adaptivity. The lcarning capabilitics of the CMAC network for a variablcstructure system have becn analyzed and the results for an arbitrary tracking problem have becn given. The results show that the CMAC control scheme used here can efficiently learn to control a complex nonlincar system and provide improved performance over that achicved with a PID optimally designed for this system.

The solution of this dynamic control problem with CMAC is an cncouraging demonstration of "cxpcricncc-based", as opposed to model-bascd, control techniques, and constitutes a good cxample of the use of on-line learning in adaptive ncural control. Ongoing work in this rescarch arca is aimed at thoroughly validating the arm control scheme for subscquent hardware implementation.

\section{ACKNOWLEDGEMENTS}

This rescarch work was partially funded by the ESPRIT III program of the EEC, under project No. 6715 "Robot Control based on Ncural Network Systcms". Rescarch in ncural control at the Instituto de Cibcrnćtica is partially supported by the rescarch grant CICYT-TAP94-0552-C03-01 of the Spanish Scicnce and Technology Council. Mr. Sardá was supportcd by CONICIT and BAUXILUM (Venczucla).

\section{REFERENCES}

Albus, J. (1975). A ncw approach to manipulator control: the Ccrcbcllar Model Articulation Controller (CMAC). Trans. of the ASME. Journal of Dynamic System, Measurement and Controls No. 97, pp:220-227.

Ananthraman, S. and D. P. Garg (1993). Training backpropagation and CMAC ncural nctworks for control of a SCARA robot. In: Engineering Applications of Artificial Intelligence. Pcrgamon Prcss. 
Cembrano, G. and G. Wclls (1992). Ncural nctworks for control. In: Application of Artificial Intelligence in Process Control (R. A. Vingerhocds L. Boullart, A. Krijgsman, Ed.). pp. 388-402. Pergamon Prcss.

Cembrano, G. and G. Wclls (1995). Neural identification of the orangc-harvesting robot. In: Deliverable Report No. 4 (ESPRIT-III Project No. 6715, Ed.). Robot Control Based On Ncural Network Systems.

Hoskins, D. A., J. N. Hwang and J. Vagners (1992). Itcrative inversion of ncural networks and its applications to adaptive control. IEEE Trans. on Neural Networks.

Hunt, K. J., D. Sbarbaro, R. Zbikowski and P. J. Gawthrop (1993). Neural nctworks for control systcms - a survey. In: Automatica. Vol. 28(6). Pcrgamon Press.

Lokc, R.E. and G. Ccmbrano (1994). Ncural adaptive control of a biorcactor. In: Intelligent Components and Instruments for Control Applications (Cs. Bányász, Ed.). Vol. 2. pp. 182187. John Wilcy. Budapest, Hungary.
Miller, W.T., F.H. Glanz and L.G. Kraft (1987). Application of a general learning algorithm to the control of robotic manipulators. Journal of Robotics Rescarch 6(2), 84-98.

Miller, W.T. (1994). Rcal-time ncural network control of a biped walking robot. IEEE Control Systems 1(2), 41-48.

Narcndra, K. S. and K. Parthasarathy (1990). Identification and control of dynamical systcms using ncural networks. IEEE Transactions on Neural Networks.

Sharbaro-Hofer, D., D. Neumerkel and K. Hunt (1993). Ncural control of a stecl rolling mill. IEEE Control Systems.

Tzirkel-Hancock, E. and F. Fallsidc (1992). Stable control of nonlincar systems using neural networks. In: International Journal of Robust and Nonlinear Control. Vol. 2. John Wilcy.

Zomaya, A. Y. and T. M. Nabhan (1993). Centralized and decentralized ncuro-adaptive robot controllers. Neural Networks 6, pp:223-244. 